\title{
Application of Monte Carlo Simulation for Free Piston Engine Cylinder Block Design
}

\author{
Nuraini Abdul Aziz, Ahmad Kamal Ariffin Mohd. Ihsan, Mohd. Jailani Mohd. Noor \\ and Nordin Jamaluddin \\ Department of Mechanical and Materials Engineering \\ Faculty of Engineering \& Built Environment, \\ Universiti Kebangsaan Malaysia \\ 43600 UKM Bangi, Selangor, \\ Malaysia \\ Phone: 03-8921 6500/03-8946 4382 \\ Email:anna.ziza@gmail.com \\ Received Date: $28^{\text {th }}$ August 2006 Accepted Date: $7^{\text {th }}$ March 2007
}

\begin{abstract}
This paper presents a stochastic simulation study to take account these uncertainties in a cylinder block structure of free piston engine. The computational stochastic structural mechanics and analysis allows a rational treatment of statistical uncertainties involved in structural analysis and design. It consists a stochastic simulation of the static analysis of the model structure where the analysis was executed from finite element software. The simulation study produces a data that identify the design input and output parameter that need to be optimised based on Monte Carlo method. By executing the design improvement analysis in the simulation process, multiple solutions arrived from the target behaviour, which have been specified for the structure. For this cylinder model, it is found that from improvement design there is a significant reduce in stress value of $18.2 \mathrm{MPa}$, modulus of elasticity for material $1, E_{1}$ of $160,200 \mathrm{MPa}$ and increasing in modulus of elasticity for material $2, E_{2}$ of $71,100 \mathrm{MPa}$ by controlling the target behaviour maximum displacement of the cylinder, $L_{\max }$. The correlations between these variables were shown in the study, which allow designers to identify the strength of the relationship between variables and the uncertainties in the design.
\end{abstract}

Keyword: Stochastic simulation, uncertainties, cylinder block, Monte Carlo.

\section{ABSTRAK}

Kertas kerja ini membentangkan kajian menggunakan kaedah simulasi stokastik dalam mengambil kira faktor ketidaktentuan pada struktur blok silinder bagi enjin omboh bebas. Analisis dan kaedah perkomputeran stokastik bagi struktur mekanik memberikan pendekatan yang rasional dalam melibatkan ketidaktentuan secara statistik dalam menganalisis dan mereka bentuk sesuatu struktur. Kajian ini mengandungi simulasi stokastik bagi analisis statik model strukturyang telah dilaksanakan menggunakan perisian kaedah terhingga. Kajian simulasi ini menghasilkan data yang dikenal pasti sebagai masukan bagi reka bentukjuga parameter keluaran yang perlu dioptimumkan berasaskan kaedah Monte Carlo. Dengan melaksanakan analisis pembaikan reka bentuk dalam proses simulasi, beberapa penyelesaian telah diperolehi hasil dari sasaran 
kelakuan yang telah dikenal pasti untuk struktur tersebut. Daripada simulasi pembaikan reka bentuk, didapati bahawa dengan mengawal sasaran kelakuan iaitu anjakan maksimum silinder, $L_{\text {max }}$ terdapat pengurangan dalam tegasan yang memberi nilaisebanyak 18.2 MPa,juga nilai modulus kekenyalan bahan 1, $E_{1}$ iaitu 160,200 MPa namun terdapat peningkatan dalam modulus kekenyalan bahan 2, $E_{2}$ iaitu 71, 100 MPa. Kajian ini membentangkan perkaitan antara pembolehubah yang mana ianya dapat membantu pereka bentuk dalam mengenal pasti kekuatan perhubungan antara pembolehubah-pembolehubah juga ketidaktentuan yang ujud dalam reka bentuk.

Kata kunci: Simulasi stokastik, ketidaktentuan, blok silinder, Monte Carlo.

\section{INTRODUCTION}

The analysis of structural behaviour is usually performed for specified structural parameters and loading conditions. A conventional numerical analysis like finite element utilizes a minimum and maximum values of the structural parameters. But in real life structural systems, the parameters are characterized by inherent randomness. Most mechanical and structural systems operate in random environments (Marczyk, 1999). In most practical situations, the major sources of such randomness can be identified in uncertainty of material properties, loading conditions, etc for example, there may be measurement inaccuracy in the manufacture process. Therefore, the concept of uncertainty plays an important role in the engineering design problems. The most common approach to problems of uncertainty is to model the structural parameters as random variables.

Stochastic is synonymous with "random". It is used to indicate that a particular subject is seen from point of view of randomness. Stochastic is often used as counterpart of the word "deterministic," which means that random phenomena are not involved.Therefore, stochastic models are based on random trials, while deterministic models always produce the same output for a given starting condition (Origlio, 2002). The system needs a probabilistic approach as a realistic and rational platform for both design and analysis. Stochastic procedures have provides the rational treatment of the uncertainties in the assessment of loading, material and geometric properties of the structure using the probability and statistic approach.

Parameter uncertainties are typically specified in terms of interval analysis, membership functions and probability density functions (PDFs). The main characteristics of the interval analysis are the variables represent lower and upper bounds was the least accurate method for uncertainty modelling (Crespo, 2002). As for membership functions, fuzzy logic is the basis for assessing the uncertainties in the system output, which provides an intermediate level of detail. The uncertainties using PDFs are referred as the probabilistic methods that provide the best description of the uncertain parameters by treating them as random variables. Monte Carlo Simulation (MCS), Importance Sampling, Latin Hypercube Sampling and Generalized Cell Mapping are among the numerical methods commonly used to estimate PDFs (Schuëller, 2001).

In this study, the stochastic method incorporates uncertainty and variability based on MCS. The study involved the static analysis of cylinder block model of a free piston engine that used a predicted maximum combustion pressure around $7 \mathrm{MPa}$. The modelling of the component was performed in finite element software in order to assign its maximum boundary conditions, materials properties and its constraints position. The stochastic simulation was conducted using different software, which used MCS based method. The results from the simulation process will give the desired output and identify the uncertain and correlation among the design variables of the components.

\section{STOCHASTIC MODELING AND PROCESS}

Stochastic modelling aims on the characterizing the different random variables that describe the uncertainties involved in the system. Basically, the structural problems involved loading and resistance variables such as pressure and Young's modulus. As mentioned by Herman et al, the load effects in a structure depend on a set of variables that are structure-independent which characterize the loading and several structuredependent parameters. For example, on the 
strength side, plastic yielding of the structure is depends on the state of stress distribution as well as on the geometry and material properties.

In stochastic models of strength, several geometric variables are involves, which can be modelled as random to take into account the uncertainties in fabrication or in measurement procedures including the material properties. as applied to an arbitrary physical system by assuming the evolution of the system can be described by PDF. Then the MCS will proceed by sampling from this PDF, which necessitates a fast and effective way to generate random numbers uniformly distributed on the interval.

By introducing Monte Carlo method (Verena, 1996) in the analysis, for a continuous random

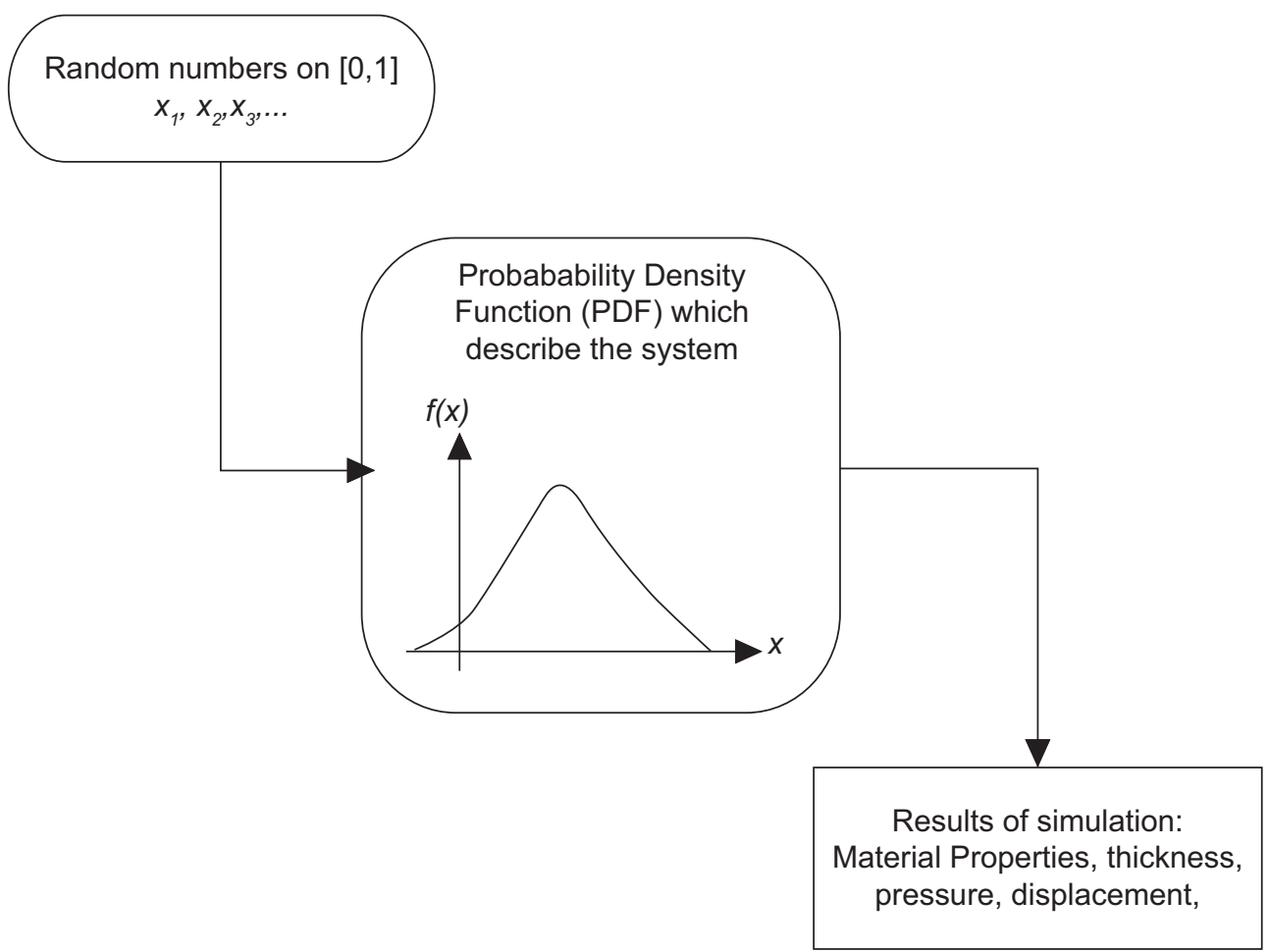

FIGURE 1. Monte Carlo Simulation of a system

Stochastic analysis is an analysis that related to a process involving a randomly determined sequence of observations, where each of is considered as a sample of one element from a probability distribution. The uncertainty parameters in the distribution are treated as continuous random variables. The random variable was distributed according to the prescribed density function. PDF described a probabilistic function where the results were an estimated value. In order to find more accurate results, statistical simulation method can be used to generate an artificial data that exhibit the same mechanical behaviour as experimental data (Mahnken, 2004).

Stochastic simulation shows the uncertain variable was simulated using MCS technique as illustrated in Figure 1. The figure illustrates the idea of Monte Carlo, or statistical simulation variables, $x^{\prime}$, the PDF defines the probability that, when the variable is sampled, a value lying in the range $x$ to $x+d x$ is $f(x) d x$ as in Figure 2 and it can be written as:

$$
\begin{aligned}
& \operatorname{prob}\left(x \leq x^{\prime} \leq x+d x\right) \equiv P\left(x \leq x^{\prime} \leq x=d x\right) \\
& =f(x) d x
\end{aligned}
$$

and if, $f(x) \geq 0 \quad-\infty<x<\infty$

then $\int_{-\infty}^{\infty} f\left(x^{\prime}\right) d x^{\prime}=1$

The most important distribution is the Cumulative Distribution Function (CDF) where it has become the basic distribution in MCS. The CDF gives the probability that the random function, $x^{\prime}$ is less than or equal to $x$ as illustrate in Figure 3 and can be written as:

$$
\begin{aligned}
\mathrm{CDF} & \equiv \operatorname{prob}^{\infty}\left(x^{\prime} \leq x\right) \equiv F(x) \\
& =\int_{-\infty}^{\infty} f\left(x^{\prime}\right) d x^{\prime}
\end{aligned}
$$




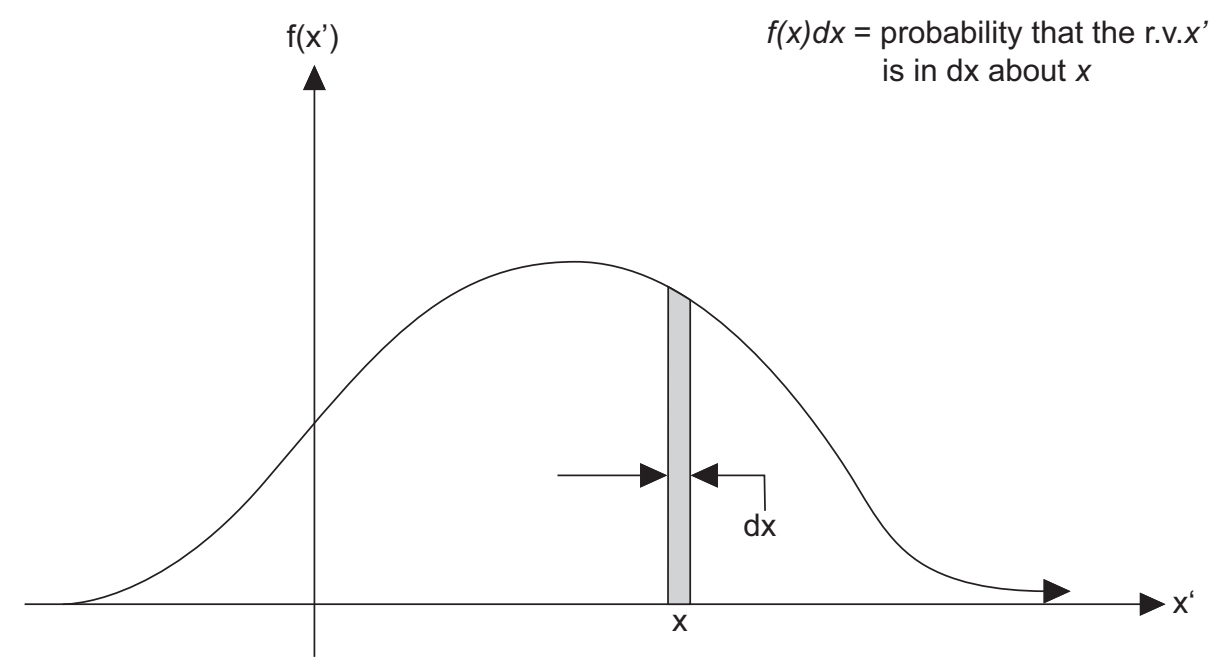

FIGURE 2. Probability distribution function

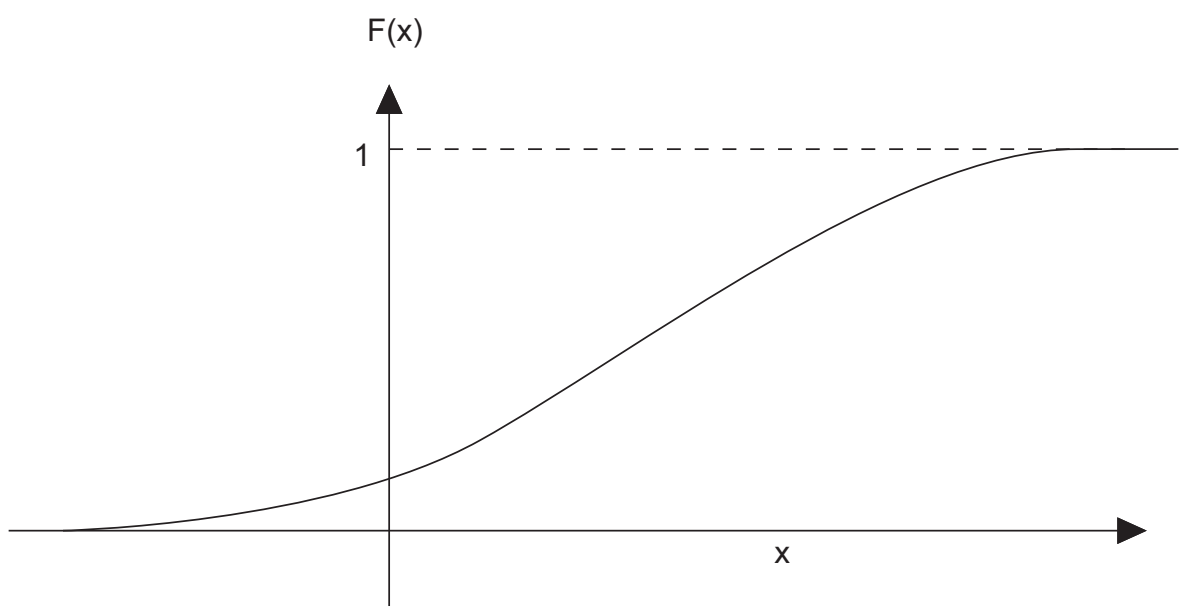

FIGURE 3. Cumulative distribution function

where $F(x)$ properties obeys the following conditions, 1) $F(x)$ non-decreasing, 2) $F(x) \in[0,1]$ and 3) $F(-\infty) 0$ and $F(\infty)=1$.

From the cumulative distribution, MCS will proceed the sampling process by reading a quantiles, $q$ of the distribution. A quantiles is an inverse form of the CDF by generating a sample, $p$ from the $C D F, F(x)$. The quantile transformation procedures are (Marczyk, 2003):

- Sample a uniform random number, $p$ in $[0,1]$, which known as:

$$
\mathrm{F}\left(x_{p}\right)=p
$$

- Read the quantile function, $q(p)$ from the distribution

- Invert the quantile function and solve for the simulated value, $x_{p}$

$$
q(p)=F^{-1}(p)=x_{p}
$$

For each design variables with uncertainties, the possible values are defined by means of probability distribution such as Gaussian/Normal, Weibull, Uniform, Logarithmic and Discrete. Gaussian distributions, $g(x)$ are mainly used in the simulation process in order to know how the structure behaves. The distribution is characterized by its two parameters, the mean, $m$ and the variance, $\sigma$ :

$$
g(x)=\frac{1}{\sigma \sqrt{2 \pi}} \exp \left[-\frac{1}{2}\left(\frac{x-m}{\sigma}\right)^{2}\right]
$$

\section{STOCHASTIC SIMULATION}

Stochastic simulation with finite element model starts by specifying the tolerances and scatter of all the input variables used in the model. In the static analysis of three-dimensional model of the 
cylinder block component, the stiffness matrix might be random due to unpredictable variation of some material properties, random coupling strength between components, uncertain boundary conditions, etc. The block structure, which is compounded with liner as shown in Figure 4, was given a maximum predicted combustion pressure, $P_{1}$ of $7 \mathrm{MPa}$ at the upper edge of the liner.There were also two preloaded pressure, $P_{2}$ and $P_{3}$ occur at the upper and inner hole at the block respectively. Since the material is compounded, there are two type of material properties used in the analysis, which are iron (material 1) and aluminium (material 2) for liner and block respectively.

$$
\left(\frac{1}{E}\right)\left(\sigma+v P_{1}\right) x d
$$

The model is executed for number of times (50 - 100), using Gaussian distribution to identify how the model performed and provide the information on the model outputs. The outputs indicate the correlation between the variables and its performance scatter also identifies variable that influence the output most. The correlations between two variables express the strength and relationship between the variables also take into account the scatter in other variables in the system. The correlation values

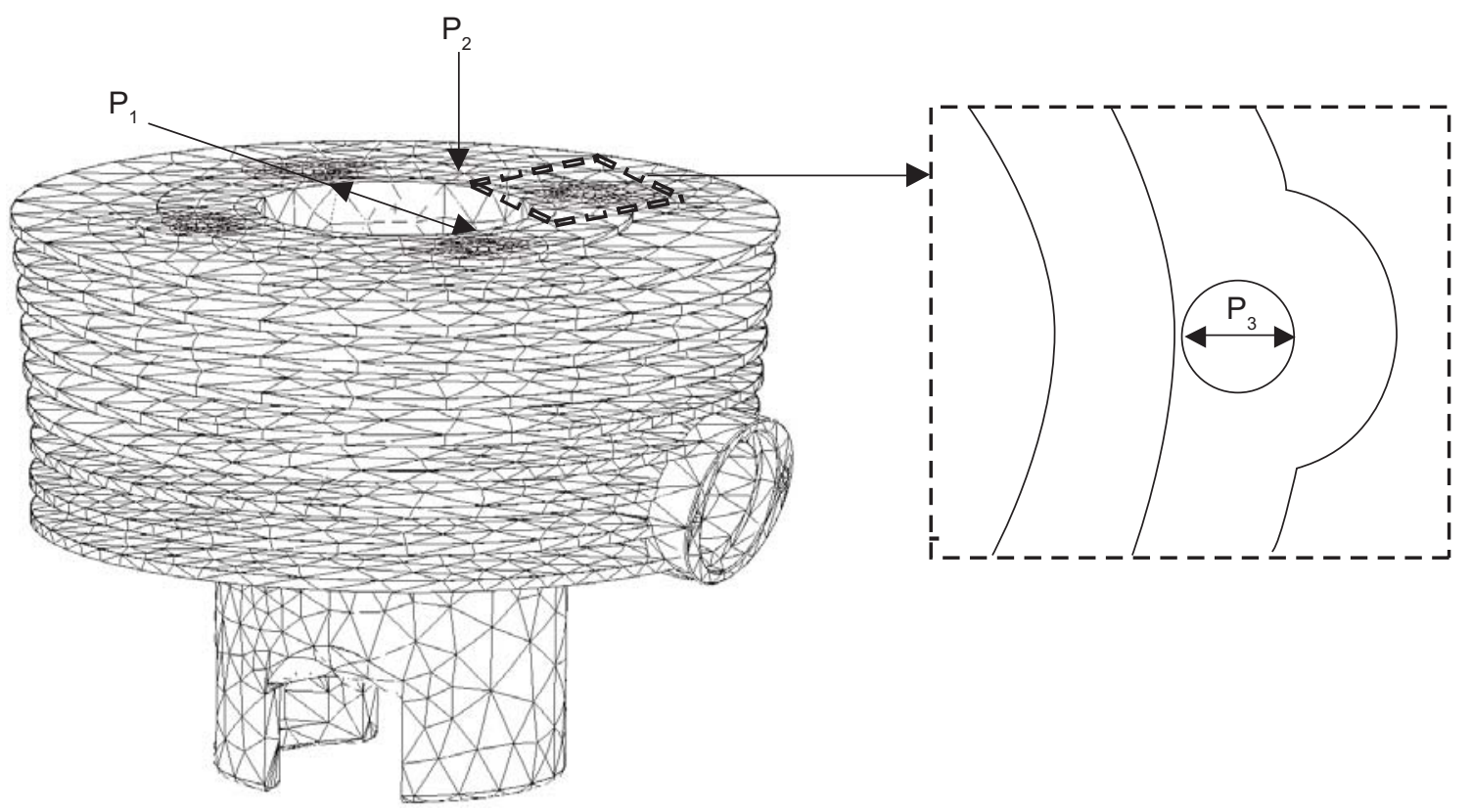

FIGURE 4. Finite element model of engine cylinder block

For this particular compounded structure, generally the inner tube or liner is put into compression and the outer part will be in tension. When an internal pressure is applied it will causes a tensile hoop stress at the inside of the outer tube which will make the liner diameter decrease and the outer liner diameter increased as shown in equation (8), and (9) (Ryder, 1969). For inner liner diameter, it is decreased by,

$$
\left(\frac{1}{E}\right)\left(\sigma-v P_{1}\right) x d
$$

where $d$ is the diameter. For the outer liner diameter is increased by, range from -1 to 1 , where value close to either -1 or 1 indicates a strong correlation. Two type of possible correlation coefficient were used in the simulation process, which are (MSC.Robust Design, 2004):

- Pearson's correlation coefficient (or linear correlation coefficient), $r$, which measures the linear correlation between variables. For two stochastic variables, $x$ and $y$ with $i=1 \ldots \mathrm{N}, r$ is:

$$
r=\frac{\sum_{i}\left(x_{i}-m_{x}\right)\left(y_{i}-m_{y}\right)}{\sqrt{\left[\sum_{i}\left(x_{i}-m_{x}\right)^{2}\left(y_{i}-m_{y}\right)^{2}\right]}}
$$


- TheSpearman rankcoefficient (ornon-linear correlation coefficient), $r_{s^{\prime}}$ is more reliable in determining significant relationship between the variables. The computation of the correlation is performed by ranking the variables from the highest to lowest assigning from 1 to N.The ranking is used to create Pie Charts to show the influence of inputs on outputs. The rank, is computed as the linear correlation between the ranks of $x_{i^{\prime}} R_{i}$ and the ranks of $y_{i^{\prime}} S_{i^{\prime}}$ which is:

$$
r_{s}=\frac{\sum_{i}\left(R_{i}-m_{x}\right)\left(S_{i}-m_{y}\right)}{\sqrt{\left[\sum_{i}\left(R_{i}-m_{R}\right)^{2}\right]\left[\sum_{i}\left(S_{i}-m_{s}\right)^{2}\right]}}
$$

From the simulation, decision map will shows the relation between the input variables and the output. The information will assist for better results by simulating the design improvement process. In this process, the specified target values, which incorporate tolerance, were assigned in the output variables. Figure 5 shows the flow chart of the overall simulation process.

\section{RESULTS AND DISCUSSION}

Stochastic simulation enable to identify the relationship between the input and output variables of the cylinder block static analysis as illustrated in the decision map in Figure 6. This map indicated the relation between the strongest input variables and output variables based on the stochastic process. From the model health simulation results for 100 times executions, the decision map shows the relation between $P_{1}$ and two output variables, which are maximum displacement magnitude, $L_{\max }$ and maximum von Mises stress, $S_{\max }$.

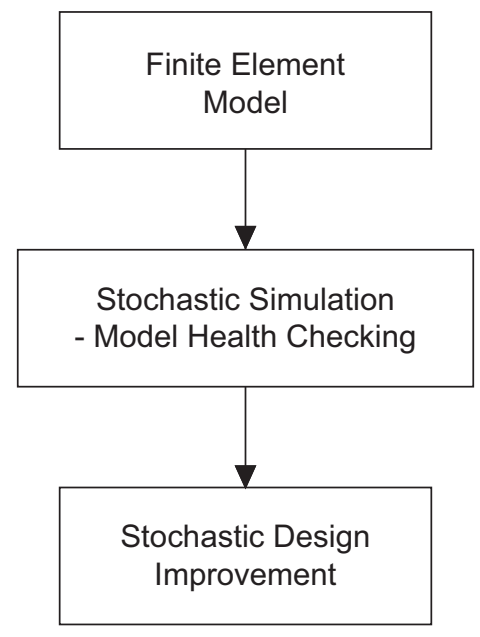

FIGURE 5. Flow-chart of stochastic simulation process

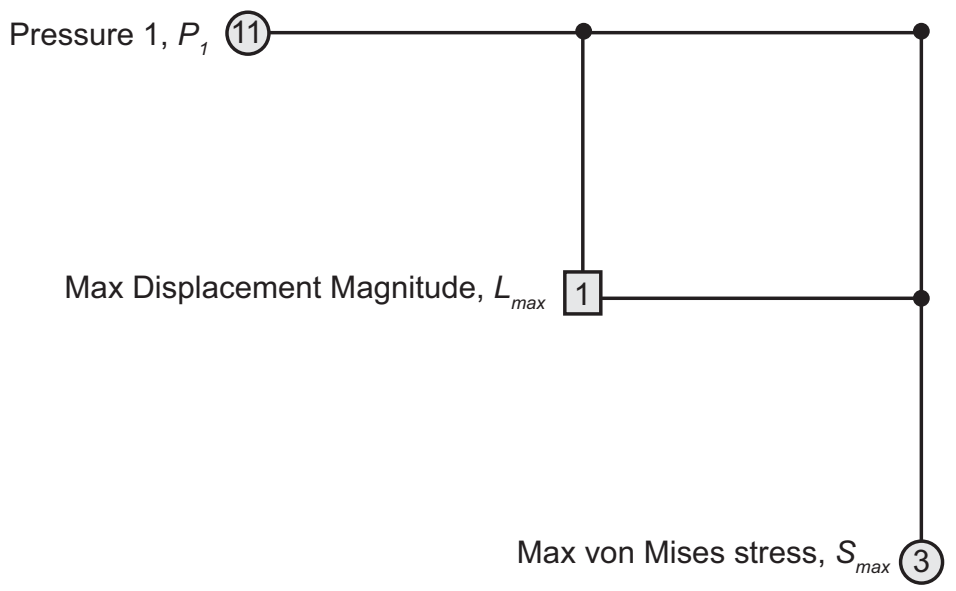

FIGURE 6. Decision map of stochastic simulation 


\section{Max von Mises stress, $S_{\max }$}

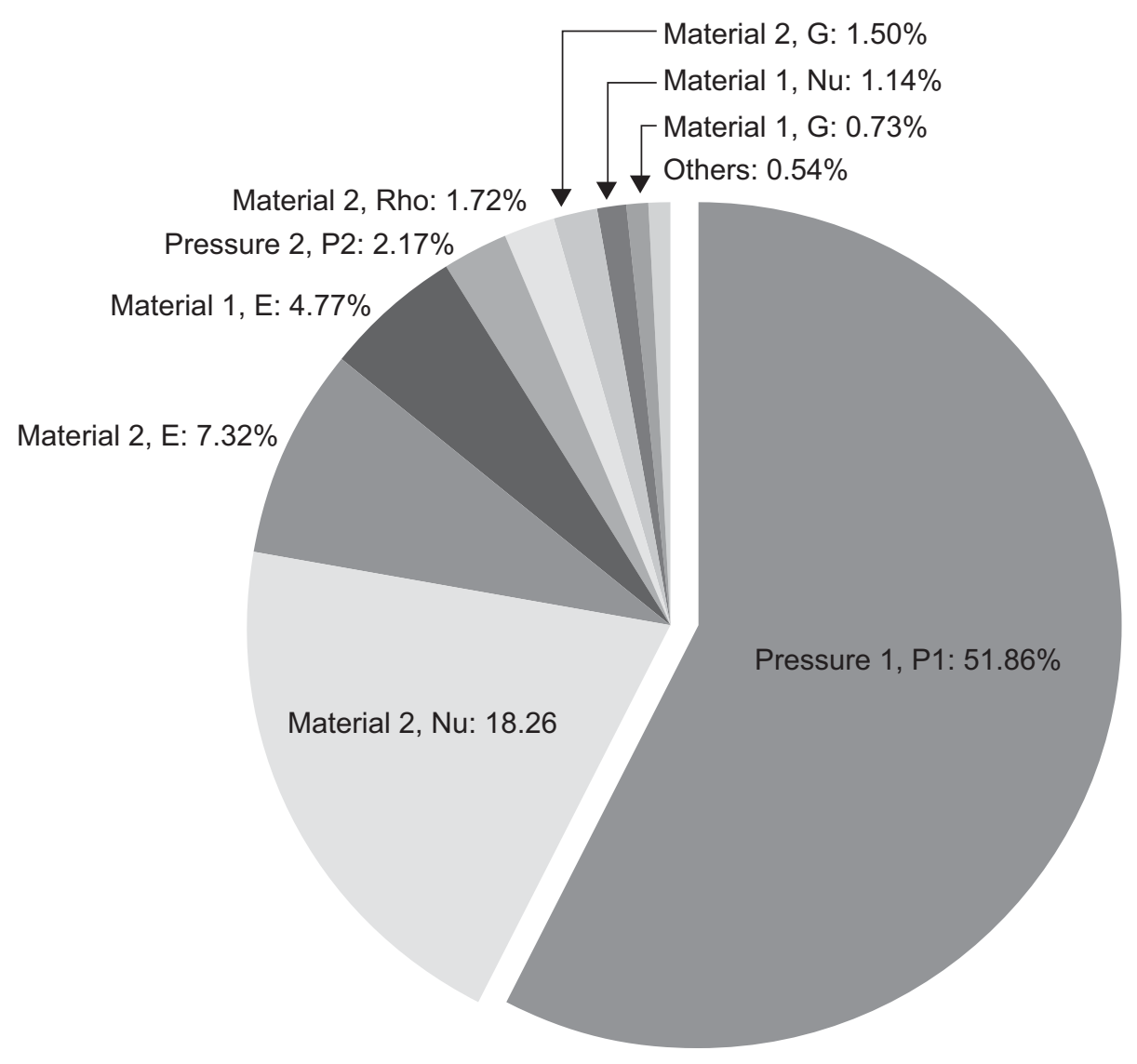

FIGURE 7. Pie chart of Max von Mises stress

In the pie chart in Figure 7, it shows that $P_{1}$ contribute 61.86 percent of overall result for $S_{\max }$ since stress and pressure has a linear relationship. Even though the pie chart of the $S_{\max }$ shows that $P_{1}$ indicated as the most influential variable, there were other variables that gave certain effect to the outputs, which are the $\mathrm{Nu}$ or poison ratio, $v$ and Young's modulus, $E_{2}$ of material 2, which is aluminium for block material. It is also known that stress have linear relationship with $E$ and strain where strain is relate with $v$. From the pie chart it shows that the most influential material affecting the stress value of the compounded block structure is aluminium.

The graph in Figure 8 indicates a linear positive correlation of 0.952 between $S_{\text {max }}$ and $P_{1}$ with the most likely value of the stress is $\mathbf{1 8 . 5}$ $\mathrm{MPa}$ at $P_{1}$ equal to $7.06 \mathrm{MPa}$, which is slightly higher than the maximum predicted combustion pressure of $7 \mathrm{MPa}$. This phenomenon explained the uncertainty of the analysis where tolerance was taken as uncertainty factor, which occurred in the input and output value of the variables.
For maximum displacement, $L_{\text {max }}$, the decision map in Figure 6 shows that the relation with $P_{1}$ and $S_{\text {max }}$. As shown in Figure 9, $P_{1}$ indicates about 44.49 percent from overall variables that influential $L_{\max }$. Two other variables that also contribute in displacement of the structure are $E_{1}$ and $E_{2}$ with 26.37 and 16.97 percent respectively. As stated, this is due to the tensile hoop stress that occurred at the inside of the outer liner tube. It also shows strong positive linear correlation of 0.809 between $L_{\max }$ and $P_{1}$ as shown in Figure 10 with the most likely values of displacement is $0.283 \times 10^{-2} \mathrm{~mm}$ at $P_{1}$ equal to $7.06 \mathrm{MPa}$.

From the correlation graphs in Figure 8 and 10 , both $S_{\max }$ and $L_{\max }$ shows that the most likely value for $P_{1}$ is $7.06 \mathrm{MPa}$. By using $L_{\max }$ as the target variable, an improvement has been made in order to get better results for $L_{\max }$. In the stochastic design improvement (SDI), the soft target variable is set for $L_{\text {max }}$ and the Young's modulus, $E$ for both materials were set as design variable. In statistical point of view, the most likely value from the previous simulation was taken as the mean 
Max von Mises stress, $\mathrm{S}_{\max }$

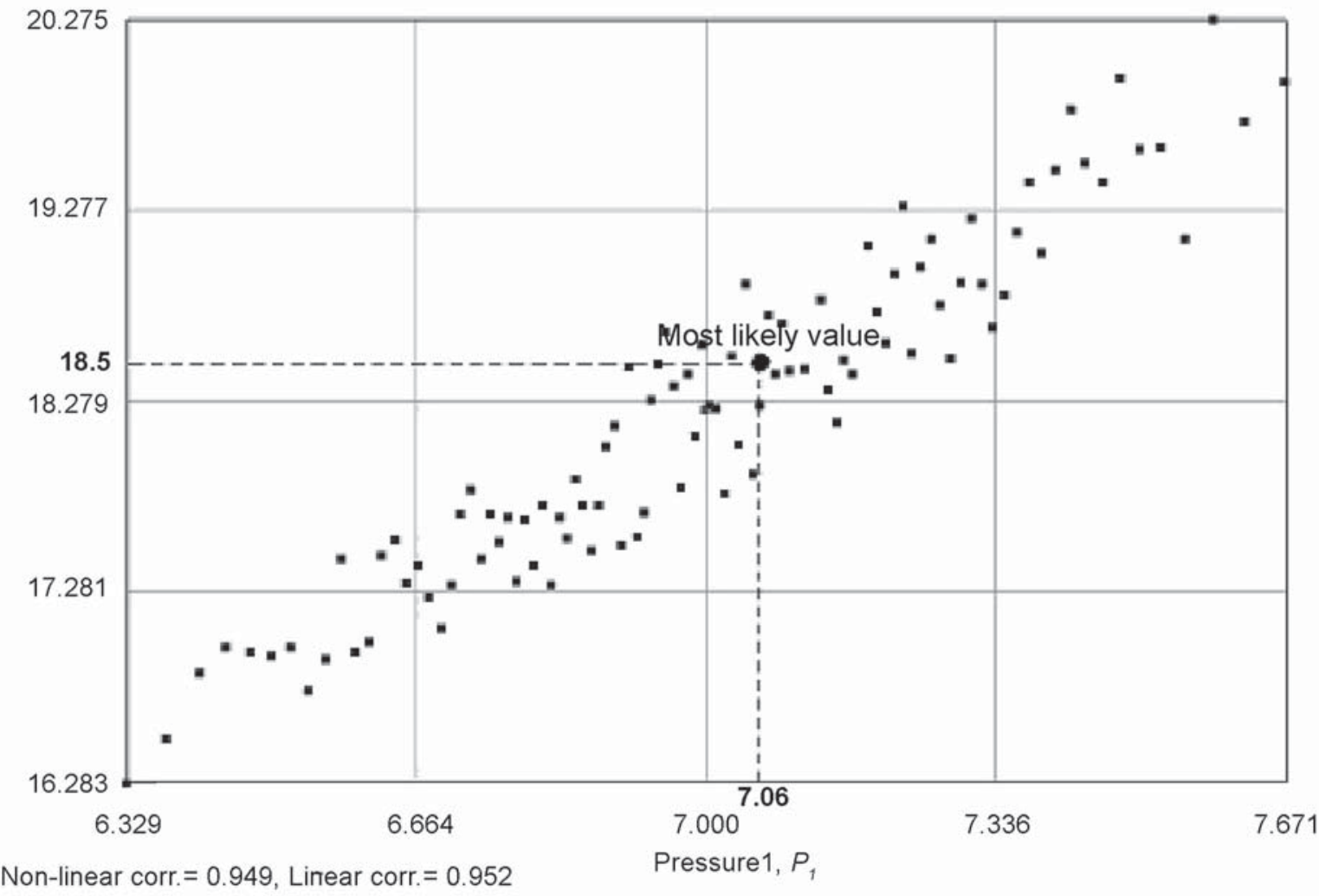

FIGURE 8. Correlation graph of von Mises stress against pressure

\section{Max Displacement Magnitude, $L_{\max }$}

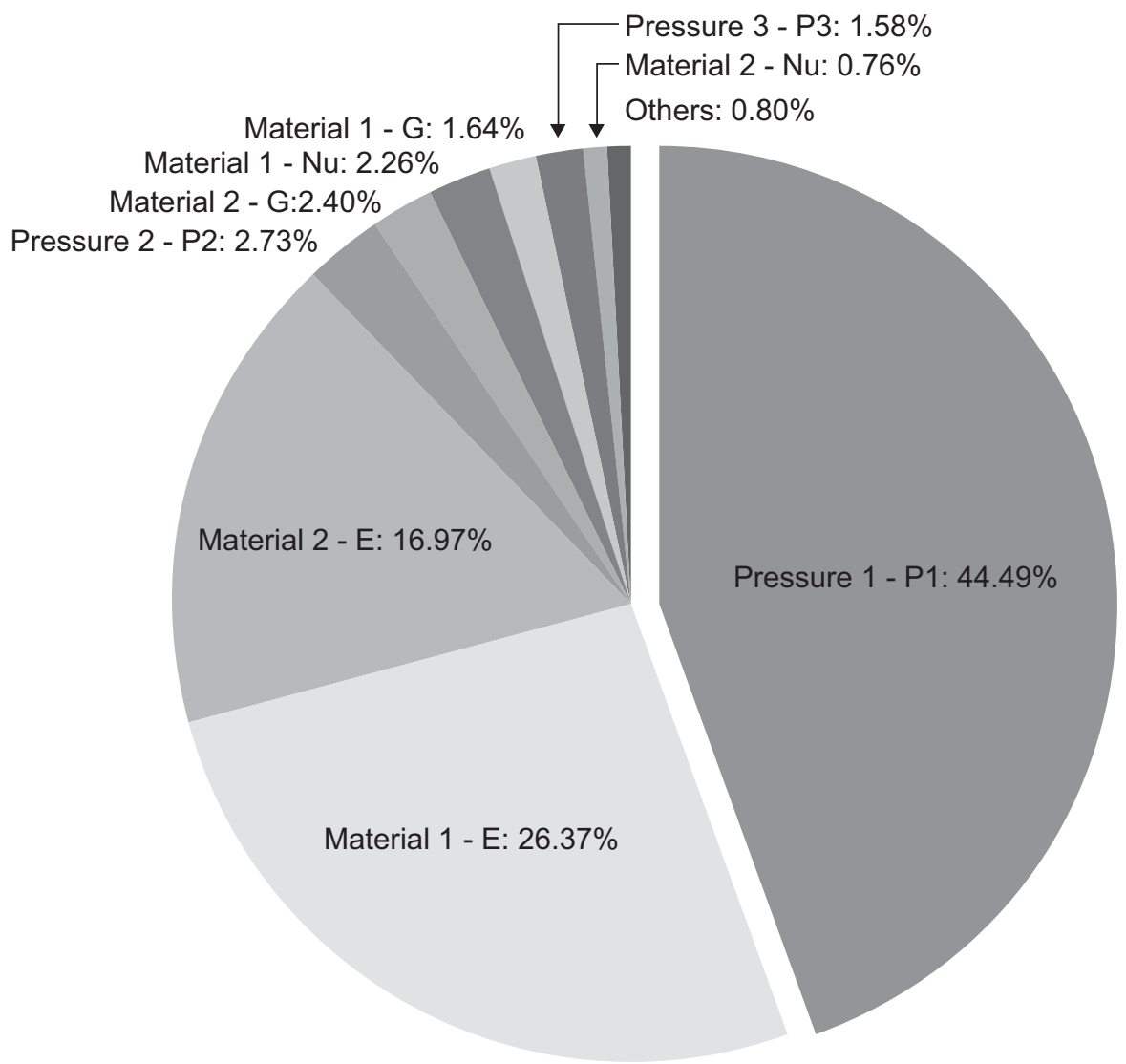

FIGURE 9. Pie chart of displacement magnitude 


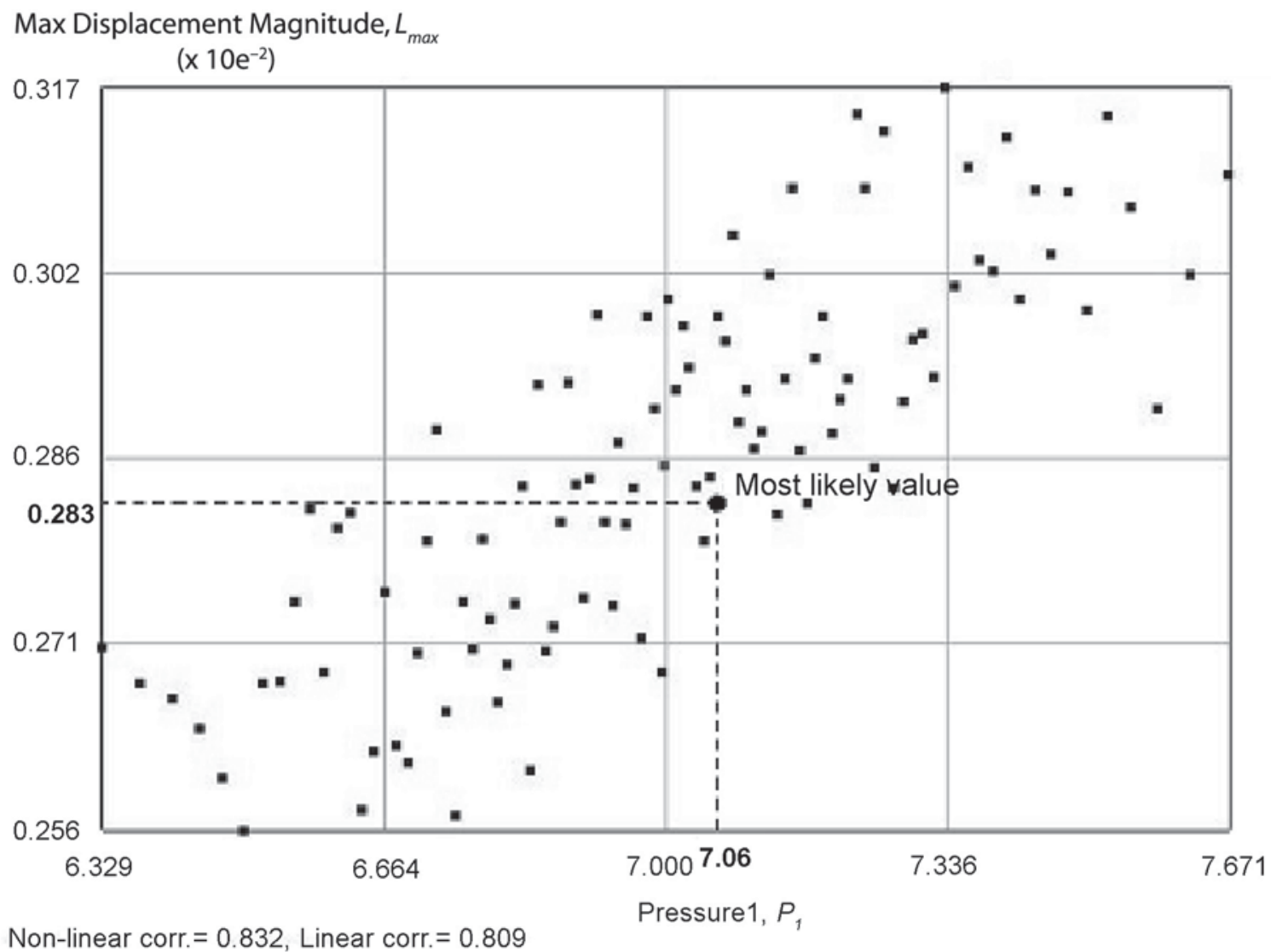

FIGURE 10. Correlation graph of displacement against pressure

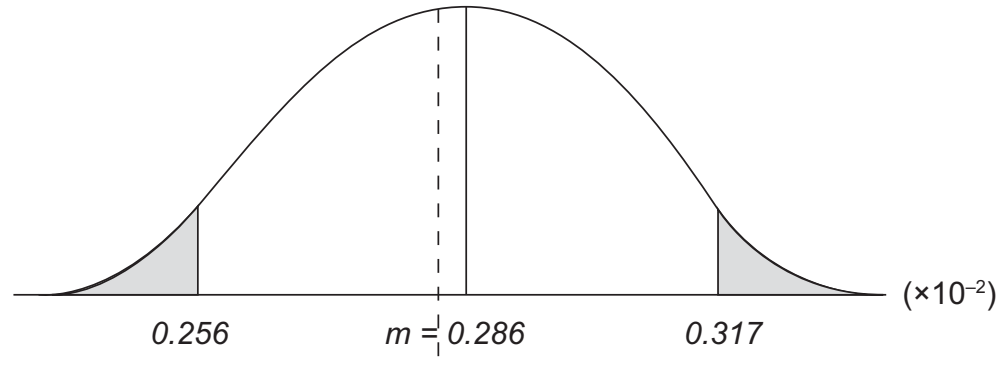

most likely value $=0.283$

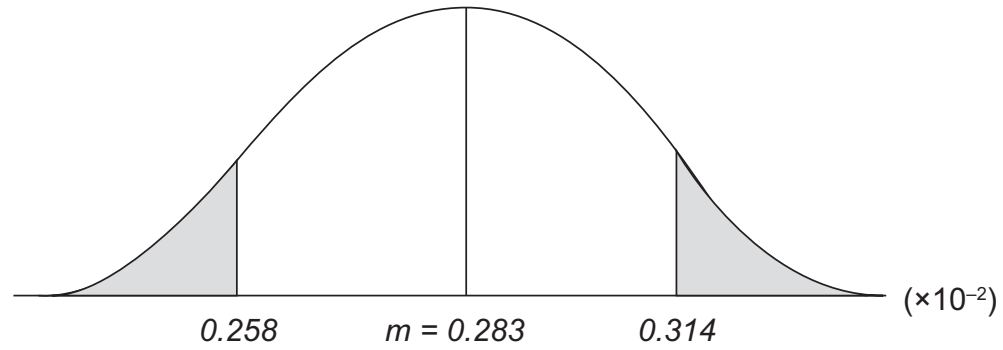

FIGURE 11. Gaussian distribution of $\mathrm{L}_{\max }$ for (a) Model health simulation (b) Stochastic design improvement 
TABLE 1. Observable simulation data

\begin{tabular}{lccccc}
\hline $\begin{array}{c}\text { Observable } \\
\text { data }\end{array}$ & $\begin{array}{c}\boldsymbol{L}_{\text {max }} \\
\left(\mathbf{x} \mathbf{1 0}^{-2}\right)(\mathbf{m m})\end{array}$ & $\begin{array}{c}\boldsymbol{S}_{\max } \\
(\mathbf{M P a})\end{array}$ & $\begin{array}{c}\boldsymbol{E}_{1}(\mathbf{M P a}) \\
(\text { material })\end{array}$ & $\begin{array}{c}\boldsymbol{E}_{2}(\mathbf{M P a}) \\
(\mathbf{m a t e r i a l ~ 2 )}\end{array}$ & $\begin{array}{c}\boldsymbol{P}_{1} \\
(\mathbf{M P a})\end{array}$ \\
\hline $\begin{array}{l}\text { Actual } \\
\text { condition }\end{array}$ & 0.286 & 18.2 & 162,700 & 68,950 & 7.00 \\
$\begin{array}{l}\text { Most likely } \\
\text { value }\end{array}$ & 0.283 & 18.5 & 164,200 & 69,570 & 7.06 \\
SDI & 0.283 & 18.2 & 160,200 & 71,100 & 6.92 \\
\hline
\end{tabular}

for new gaussian distribution in the SDI. Figure $11(\mathrm{a})$ and (b) shows the distribution before and after the SDI simulation respectively.

The area of acceptable data in the gaussian distribution of SDI has been change compare to the existing area in Figure 11(a). The existing distribution shows that the lower limit of 0.256 was increased to 0.258 in the SDI distribution. The upper limit of the existence distribution decreased from 0.317 to 0.314 in the SDI distribution. This shows that the SDI distribution was shifting to the left since the target variable is to reduce the maximum displacement as small as possible.Table 1 shows the observable data of input and output variables of both simulations. The table shows three different type of design where designers can choose according to the priority of the design. The actual condition gave higher $L_{\max }$ compared to others, given the same value of $S_{\max }$ with SDI. In terms of material properties, SDI has the lowest value of $E_{1}$ and highest value of $E_{2}$ compared to others. But for $P_{1}$ SDI gave the lowest value.

\section{CONCLUSION}

Summarize from this study explained the effect of design variables, which were treated as continuous random variable using stochastic simulation. From the static analysis of finite element model, the model health simulation has shown the relationship among the output

\section{REFERENCES}

Crespo, L. G. 2002. Optimization of System with Uncertainty: Initial Developments for Performance, Robustness and Reliability Based Designs, ICASE Report No. 2002-40, NASA/CR2002-211952.

Herman, G. M, Christoph E. B., Christian G. B., and Soares, C. G. 1997. Uncertainties in Probabilistic Numerical Analysis of Structures and Solids - Stochastic Finite Elements, Structural Safety. 19(3): $283-336$. and input variables of the design. The stochastic produced some indicator diagram such as the decision map, scatter of correlation graph and pie chart, which can be used to indicate the most influential variable. An improvement also can be made by identifying which variables influent the overall performance of the design.

From the simulation results of cylinder block analysis, even though the stress results does not effect much on the design since the maximum results is far below the yield strength, but the influence of uncertainty in $P_{1}$ and $E$ gave certain affect on the design in the data shown in Table 1. There are many combinations of results that can be used for in the design depending on the end user specifications. Designer can choose either to specified certain pressure to the block or targeting certain allowable displacement that the structure may experience. As for the analysis, since the running engine gave a maximum $P_{1}$ of 4 $\mathrm{MPa}$, it is better to choose the SDI combinations even though the $E_{2}$ value slightly higher than actual in terms of cost but it enable to reduce the $E_{1}$ value which can balance the overall cost of the design.

\section{ACKNOWLEDGEMENTS}

This project was sponsored by Malaysian Ministry of Science, Technology, and Innovation under Project IRPA-03-02-02- 0056 PR0025/ 04-03.

Mahnken, R.2004.Identification of Material Parameters for Constitutive Equations.

Erwin Stein, Rene de Borst and Thomas J.R. Hughes (Eds.), Encyclopedia of Computational Mechanics. 2:637- 656 .

Marczyk, J. 1999. Principles of Simulation-Based Computer-Aided Engineering, Madrid.

Marczyk, J. 2003. Stochastic Simulation Using MSC. Robust Design - Basic Theory, MSC. Software Corporation, USA. 
MCS.Robust Design, Version 2004 r3, User's Manual, MSC. Software Corporation, USA.

Ryder, G. H. 1969. Strength of Materials, Macmillan Education Ltd., UK.

Schuëller, G.I. 2001. Computational Stochastic Mechanics - Recent Advances, Computers and Structures. 79: 2225 - 2234.
Origlio, Vincenzo 2002. Stochastic, From MathWorldA Wolfram Web Resource. (online) http:// mathworld.wolfram.com/Stochastic.html $\left(9^{\text {th }}\right.$ May 2005)

Verena, M.U. 1996. Introduction to Monte Carlo Methods, Computational Science and Educational Project, United States. (online) http://www.phy.ornl.gov/csep (9th May 2005) 